\title{
DEVELOPMENT OPPORTUNITIES FOR AUTOMATION AND ROBOTIZATION IN POLAND
}

\author{
Iwona ŻABIŃSKA \\ Silesian University of Technology, Faculty of Organization and Management, Zabrze; Iwona.Zabinska@polsl.pl, \\ ORCID: 0000-0002-9368-4311
}

Purpose: The article aims at evaluating the automation and robotization development status in Poland, recognizing the key factors influencing the technology development in Polish enterprises and identifying the existing support in the given scope.

Design/methodology/approach: Data from secondary sources were used for the analysis in this article. The secondary data came from internal sources, such statistical offices, government administration authorities, studies and publications. Data were collected and analyzed using Excel.

Findings: The data analysis performed for the automation and robotization status in Poland shows that the available statistics are highly limited. Only one institution is currently performing large-scale research on the global robotization, while automation in Polish enterprises was researched by Statistics Poland up to 2015. If there are reports containing data on the automation status, they are very limited and recognized differently. Owing to the above, data comparison from various periods of time and various industries is challenging.

Originality/value (mandatory) The paper presents the detailed automation and robotization development status analysis in Poland.

Keywords: automation, robotization, industrial development, Poland.

Category of the paper: research paper.

\section{Introduction}

As many subject matter researchers highlight, the manufacturing process automation and robotization becomes standard, or even necessary, to ensure that enterprises remain operational and competitive (please note, that automation and robotization have different meaning, but they are often used interchangeably). Robotization includes activities performed to automate the manufacturing work with the manipulators and robots. The industrial manipulation robot is an automatically controlled, programmable and multi-task manipulation machine with many levels of freedom and manipulation or locomotion properties, stationary or mobile (ISO 8373 
- 2001 standard). Automation has a broader meaning and consists of using the equipment that takes cognitive, intellectual and decision-making activities from human. This equipment acts independently, which shows in the independent organizational structure, control process, automatic control, artificial intelligence and possibility to collaborate with other systems. According to Statistics Poland, the manufacturing process automation means may include (GUS, 2015):

- automatic manufacturing lines,

- computer controlled manufacturing lines,

- machining centers,

- numerically controlled laser machines,

- industrial robots and manipulators,

- computers for technology process control and adjustment (GUS, 2015).

The term Industry 4.0 has been recently widely used in relation the automation and robotization, as it is the fourth industrial revolution (Figure 1).

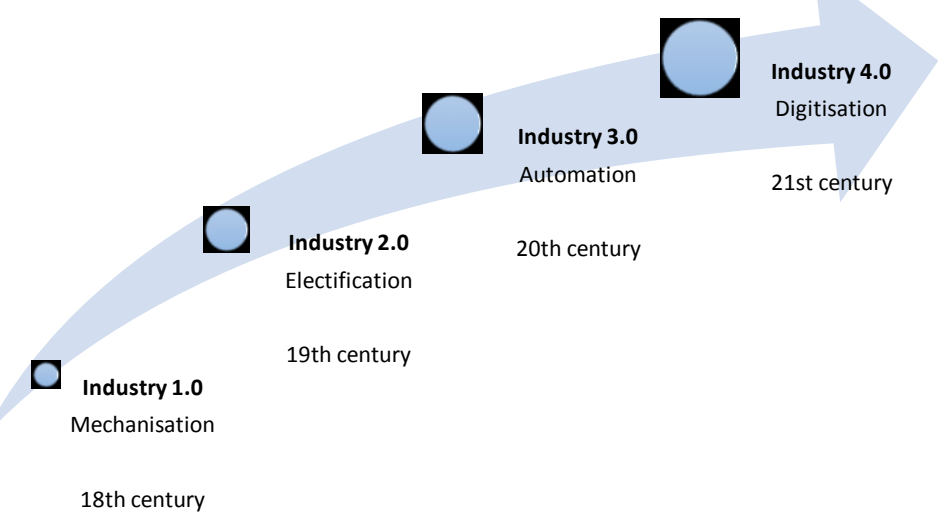

Figure 1. Industrial Revolutions. Adapted from "A Roadmap to Industry 4.0: Smart Production, Sharp Business and Sustainable Development" by A. Nayyar and A. Kumar. Copyright 2019 by Springer Nature.

Industry 4.0 should be construed as a common term that connects the added value chain technology and organization. This concept concerns the use of automation, data processing and exchange, as well as the implementation of technologies used to create cyber-physical systems (CPS). The cyber-physical system attributes are as follows:

- interoperability or the ability to communicate (by employees, infrastructure, cyberphysical systems) via the open networks and semantic descriptions,

- visualization that allows to create the virtual equivalent of the real world,

- decentralization or the ability of the cyber-physical systems to act independently,

- modularity or the ability to adapt flexibly to varying requirements by replacing or expanding individual modules (Götz, and Gracel, 2017). 
According to the report of the Industrial Development Agency, Industry 4.0 has the following features:

- automation and robotics,

- digitalization (software, teleinformation technologies),

- sensors,

- real-time communications,

- artificial intelligence (Internet of Things and artificial intelligence),

- security,

- employee expertise (Michałowski et al., 2018).

According to the researchers (Moeuf et al., 2018; Nayyar, and Kumar, 2019; Rojko, 2017), the following nine advanced technologies play a key role in "Industry 4.0": big data and analytics, simulation, Internet of things, cyber-physical systems, cloud computing, virtual reality, cyber security, collaborative robots, machine-to-machine communication.

Identification of the subsequent industrial revolutions and the creation of policy that supports their development show, that new technologies have a significant meaning for the enterprise functioning. The majority of reports ordered by government bodies (Fundowicz et al., 2018; Grzeszak et al., 2019; Michałowski et al., 2018) shows that the traditional approach to the manufacturing process and failure to follow the changes connected with the common robot adoption by the foreign competitors will lead to lost competitiveness, which will result in the enterprises being removed from the market.

\section{Robotization Status in Poland and in the World}

The International Federation of Robotics (IFR) is the main source of the global robotics development data. In Poland, the detailed data on the manufacturing process automation means in the industry was collected by GUS in the period of 2002-2014. Numerous reports are currently prepared to present the robotization status in Poland, but their thorough analysis shows that the information is sourced from the IFR data. According to the International Federation of Robotics data, the robot sales increases every year. In 2018, 422 thousand robots were sold, which constituted a 6\% sales increase compared to 2017 (Figure 2). 


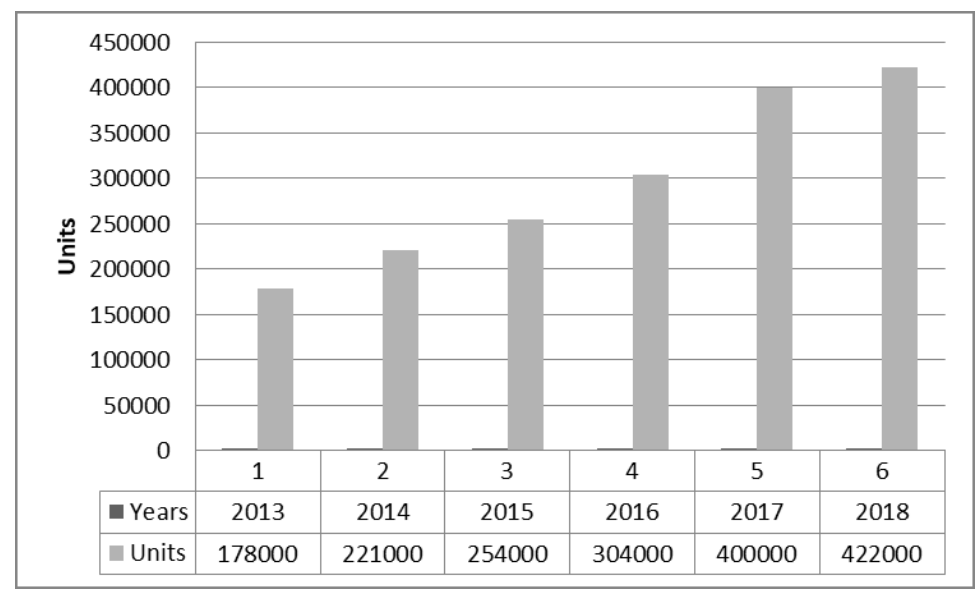

Figure 2. Annual installation of industrial robots. Adapted from „IFR World Robotics Presentation 18 Sept 2019".

According the International Federation of Robotics, the average robotization density in the global economy in 2018 was 99 industrial robots per 10 thousand industrial employees. In Poland, the robotization density in the period of 2011-2018 was from 14 up to 42 industrial robots per 10 thousand industrial workers (Figure 3). This result does not allow Poland to be ranked among 15 countries with the highest number of installed robots.

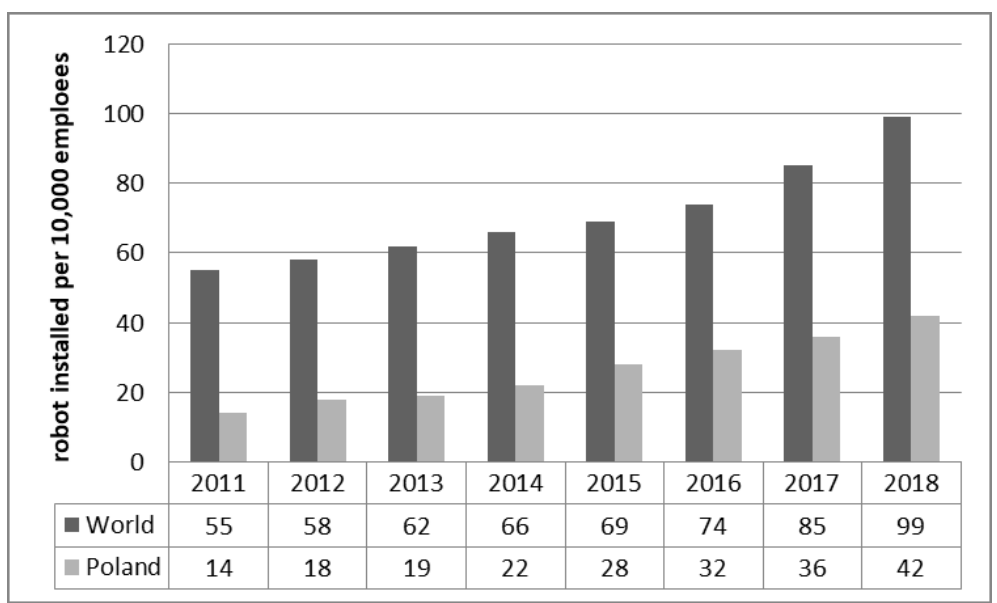

Figure 3. Average Robotization Density in Poland and in the World. Adapted from IFR reports.

The top five countries that buy the highest number of robots are China, Japan, Korea, United States and Germany. For the European countries - apart from Germany - Spain, Finland, Italy, The Netherlands, France, Sweden and Slovakia had much better indicators than Poland, as shown both in the Eurostat and the IFR statistics. Thus, Poland falls behind significantly, and the appropriate actions must be taken to support and stimulate the robotization development. 


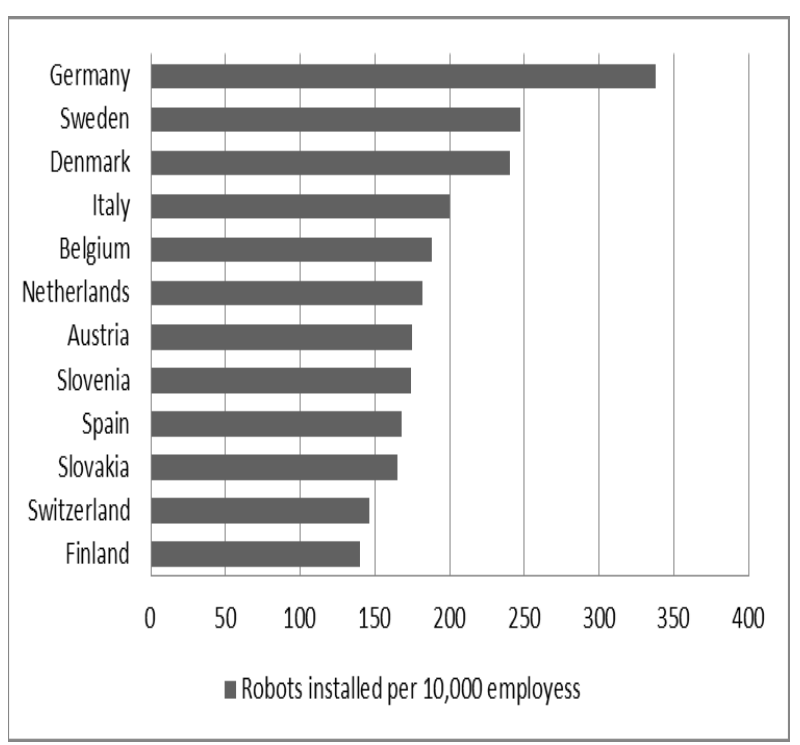

Figure 4. Robots installed per 10,000 employees from industry in 2018. Adopted from IFR report.

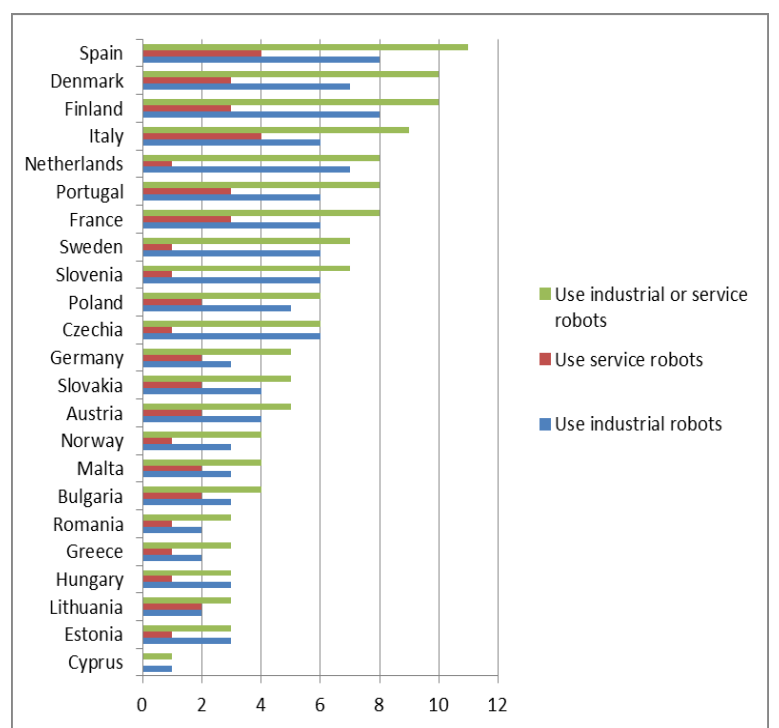

Figure 5. Percentage of enterprises using robots in 2018. Adopted from Eurostat.

In Poland, the highest number of robots is used in the automotive industry (39\%), then in the metal production and machinery construction $(22 \%)$, as well as in the chemical industry and the rubber and plastic product manufacturing (19\%) (Grzeszak et al., 2019). Over half of new robots was installed in the handling operations sector (52\%) (IFR, 2019.) The highest number of enterprises that use the manufacturing process automation means is located in Silesia, Greater Poland, Masovia, Lesser Poland, Łódź and Lower Silesia regions, while the highest number of robots and manipulators is installed in Silesia and Lower Silesia regions (GUS, 2015).

\section{Entrepreneur Position on Robotization}

As the report of the Ministry of Entrepreneurship and Technology (MPiT) and Siemens shows, the manufacturing line automation is the most common innovation supporting solution. This solution is used on average by $52 \%$ of the respondents. About $70 \%$ of medium enterprises uses manufacturing line automation and data analytics to optimize their production. According to the report authors, it is a group dominated by the robotization related solutions. Nearly $40 \%$ of the companies use robots on their manufacturing lines (Siemens, 2018).

The results of research conducted by the Institute of Economical Forecasts and Analyses show (Fundowicz et al., 2019), that $41 \%$ of the companies that do not have any robots did not consider their implementation at all. Other reasons behind failing to use robotization indicated by the companies are: 
- manufacturing process nature, that does not require installation of any robots $-30 \%$ of the companies,

- low manufacturing scale $-18 \%$ of the companies,

- no manufacturing growth plans $-7 \%$ of the companies,

- no funds.

According to the entrepreneurs who invest in robots, the most important reasons behind manufacturing robotization are as follows (Fundowicz et al., 2019):

- manufacturing efficiency increase,

- manufacturing cost reduction,

- uniform product quality maintenance,

- closing staffing gaps,

- work safety improvement.

All research explicitly shows that the companies who have implemented the manufacturing line automation or industrial robots mainly gained measurable economic benefits. The manufacturing growth, reduced manufacturing costs, increased product sales, bigger competitive advantage, improved manufacturing flexibility and higher product quality were indicated as the most important benefits (Fundowicz et al., 2019; Łapiński, 2015; Simens, 2018).

The significant result of the research performed is the determination of key factors that influence the manufacturing process automation and robotization development (Figure 6).

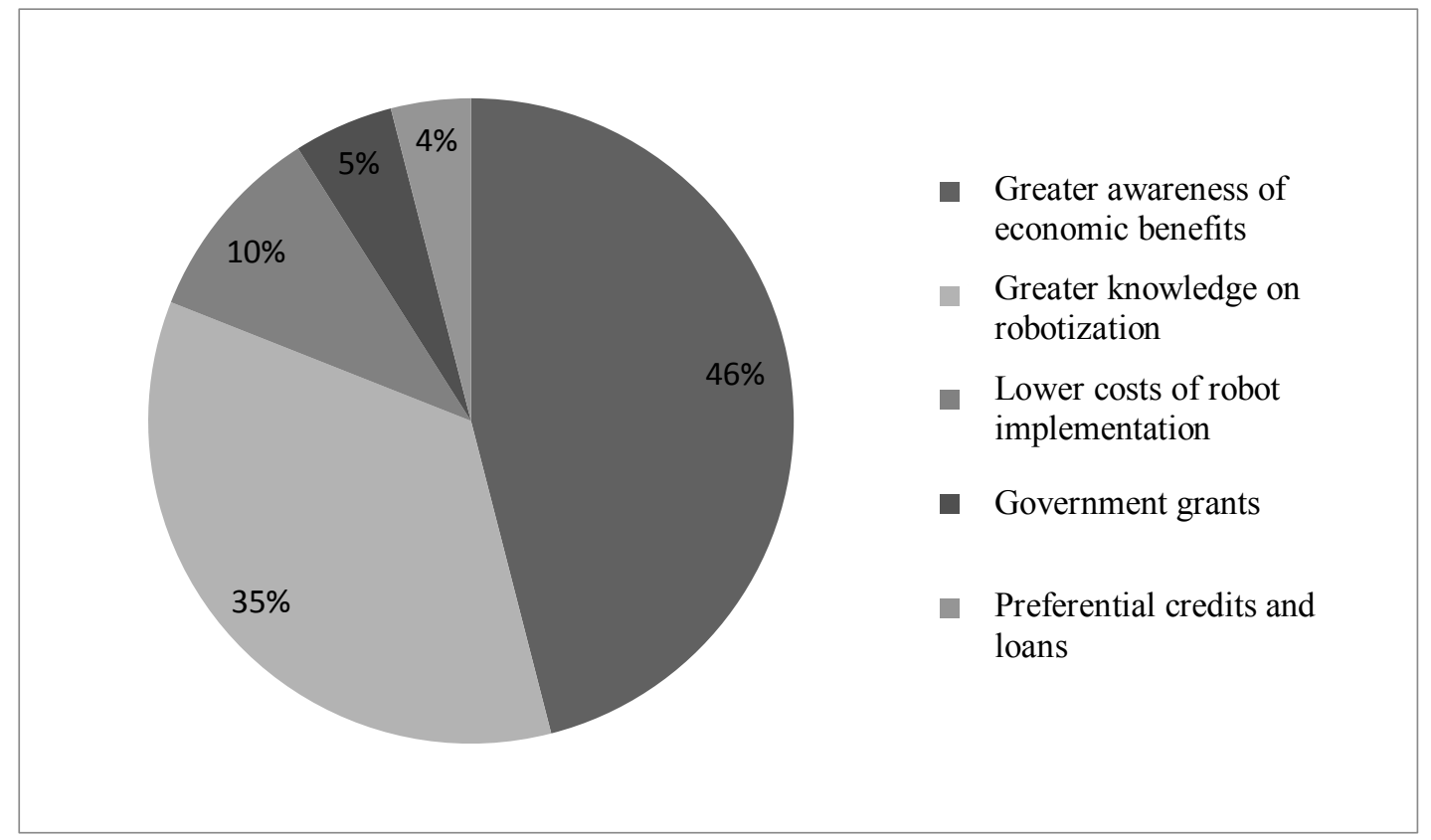

Figure 6. Factors that accelerate robotization by companies that use robots. Adopted from Fundowicz J., Łapiński K., Wyżnikiewicz B. (2019). "Wpływ robotyzacji na konkurencyjność polskich przedsiębiorstw" (Robotization Impact on Polish Enterprise Competitiveness) (Report Edition III). Warszawa. Institute of Economical Forecasts and Analyses. 
Surprisingly, the respondents state, that the access to investment fund sources is not as important as the knowledge on robotization and benefits of the implemented technologies and solutions (Fundowicz et al., 2019). On the other side, many entrepreneurs are afraid of additional costs due to the manufacturing process alteration, employee training and new equipment maintenance, even if they know that the robotization investment can pay for itself in less than a year (Michałowski et al., 2018). The MTiP report shows that the most desired state and government body actions connected with implementing the technology innovations, including automation and robotization, are tax incentives and adaptation of future staff education to the company needs (Siemens, 2019).

\section{Manufacturing Process Automation and Robotization Support Methods}

Poland and the government bodies currently do not have any tools to directly support the implementation of automation and robotization in the enterprises. However, many reports are prepared, that show foreign best practices, that can be adapted to Polish circumstances, or recommendations for the Industry 4.0 development (Grzeszak et al., 2019; Michałowski et al. 2018). Implementation of new technologies and solutions as part of automation and robotization requires high financial outlays connected with machinery, equipment and software purchase, as well as paying for the consulting services of software providers or the so-called automation integrators. Additional costs that a company that implements new technologies should consider are the required infrastructure adaptation (adapting the buildings or building new ones, security, new installation etc.), as well as training and hiring new employees to operate the automated line or robot. The direct support provided when purchasing new machinery or equipment includes:

- one-time annual depreciation deduction of up to PLN 100,000, along with the minimum outlays of PLN 10,000 under the act of 7 July 2017 on the modification of the act on the personal income tax and the act on the corporate income tax,

- leasing to purchase machinery and equipment, which is of special interest for medium and large companies, because small companies and the ones that start to operate can apply the preferential asset depreciation under the applicable laws.

The EU funds are another method of support. There are many programs, but they are mainly provided to support research and development, innovation and educational activities. Apart from that, the competition rules may change every year and the application is often very complex and does not guarantee receiving the support offered. The companies that intend to automate the research and development manufacturing are entitled to use such fiscal mechanisms as: 
- research and development operations allowance - a taxpayer is able to deduct from $200 \%$ up to $250 \%$ of expenses connected with the research and development operations,

- IP-Box allowance - a taxpayer may be subject to a preferential tax of $5 \%$ of the income from the eligible intellectual property rights,

- tax loss settlement - a taxpayer, whose tax deductible expenses exceed their revenues in the given year, is entitled to a one-time tax loss settlement of up to PLN 5 million (Article 9 section 3 of the Journal of Laws of 2016, item 2032, as amended).

Many entrepreneurs indicate that the lack of specialists who could coordinate implementation of new solutions in their companies is a significant barrier when it comes to deciding on the manufacturing process automation or robotization. In particular, this problems applies to companies that require customized technology solutions. The Future Industry Platform Foundation, established at the beginning of 2019, may resolve this problem, as it aims at transforming the Polish industry to the level called Industry 4.0 (Journal of Laws of 2019, item 229). The Foundation works, among other things, on creating the mechanisms for collaboration, sharing knowledge and building trust in the relationships between the entities involved in the digital transformation process (Article 1, item 2, of the Journal of Laws 2019, item 229).

\section{Conclusions}

Poland has no instruments that would provide direct automation and robotization development support. There are many support forms for innovation, as well as research and development operations, and it is legitimate to use such support, assuming that the operations connected with automation can sometimes constitute research and development operations. However, the research analysis shows that, according to the entrepreneurs, funds are not the main issue when deciding on the robot implementation or manufacturing process automation. The key problem is the lack of robotization knowledge and fear of the complex new technology implementation process.

It should be highlighted, that the market situation is one of the significant factors that influence the manufacturing process automation and robotization. On the one side, cheap workforce does not favor the machinery investments and, on the other hand, low unemployment rates result in the lack of workforce, so the employers start looking for alternative solutions, such as workstation robotization. 


\section{Acknowledgements}

This paper was financed from the resources of the Silesian University of Technology, project no. BK-235/ROZ-1/2020 (13/010/BK_20/0042).

\section{References}

1. Eurostat. Available online https://ec.europa.eu/eurostat/web/products-datasets//isoc_eb_p3d.

2. Fundowicz, J., Łapiński, K., Wyżnikiewicz, B. (2019). Wpływ robotyzacji na konkurencyjność polskich przedsiębiorstw. Warszawa: Instytut Prognoz i Analiz Gospodarczych.

3. Główny Urząd Statystyczny. Bank Danych Lokalnych. Available online https://stat.gov.pl/obszary-tematyczne/nauka-i-technika-spoleczenstwo-informacyjne/ nauka-i-technika/nauka-i-technika-w-2015-r-,1,12.html, 01.03.2020.

4. Götz, M., and Gracel, J. (2017). Przemysł czwartej generacji (Industry 4.0) - wyzwania dla badań w kontekście międzynarodowym. Kwartalnik Naukowy Uczelni Vistula, 1(51), 217-235. Retrieved from http://cejsh.icm.edu.pl/cejsh/element/bwmeta1.element.desklight237b8c1c-ff6c-48ed-b4ef-dd8fdc7f3397, 25.05.2020.

5. Grzeszak, J., Sarnowski, J., Supera-Markowska, M. (2019). Drogi do przemystu 4.0. Robotyzacja na świecie i lekcje dla Polski. Warszawa: Polski Instytut Ekonomiczny. Retrieved from https:/www.arp.p1/_data/assets/pdf_file/0008/89918/_Raport_ARP_ druk_po_stronie_calosc.pdf, 19.05.2020.

6. IFR World Robotics Presentation - 18 Sept 2019. Available online https://ifr.org/ downloads/press2018/IFR\%20World\%20Robotics\%20Presentation\%20\%2018\%20Sept\%202019.pdf.

7. Łapiński, K., Peterlik, M., Wyżnikiewicz, B. (2015). Wpływ robotyzacji na konkurencyjność polskich przedsiębiorstw. Warszawa. Instytut Badań nad Gospodarką Rynkową.

8. Michałowski, B., Jarzynowski, M., Pacek, P. (2018). Raport. Integracja rynku robotyki $i$ automatyki przemysłowej $z$ rynkiem teleinformatyki. Szanse $i$ Wyzwania Polskiego Przemystu 4.0. Warszawa: Agencja Rozwoju Przemysłu S.A.

9. Micheler, S. (2016). Influencing Factors for Implementing Automation in Manufacturing Businesses - A Literature Review. Conference: Advances in Manufacturing Technology XXX: 14th International Conference on Manufacturing, 14(14). Retrieved from 
https://www.researchgate.net/publication/308476064_Influencing_Factors_for_Implement ing_Automation_in_Manufacturing_Businesses_-_A_Literature_Review, 28.05.2020.

10. Moeuf A., et al. (2018). The industrial management of SMEs in the era of Industry 4.0. International Journal of Production Research. of Production Research, 56(3), 1118-1136, doi: 10.1080/00207543.2017.1372647.

11. Nayyar, A., and Kumar, A. (2019). A Roadmap to Industry 4.0: Smart Production, Sharp Business and Sustainable Development. Delhi: Springer Nature.

12. Rojko, A. (2017). Industry 4.0 Concept: Background and Overview. International Journal of Interactive Mobile Technologies, 11(5), 77-90. doi:10.3991/ijim.v11i5.7072.

13. Siemens (2018). Smart Industry Polska 2018. Innowacyjność w sektorze mikro oraz matych $i$ średnich przedsiębiorstw produkcyjnych $w$ Polsce. Raport $z$ badań. Warszawa: Ministerstwo Przedsiębiorczości i Technologii.

14. Ustawa z dnia 17 stycznia 2019 r. o Fundacji Platforma Przemysłu Przyszłości. Dz.U. 2019 poz. 229 (2019).

15. Ustawa z dnia 26 lipca 1991 r. o podatku dochodowym od osób fizycznych (Dz.U. z 2016 r. poz. 2032, z późn. zm.) (2019).

16. Ustawa z dnia 7 lipca 2017 r. o zmianie ustawy o podatku dochodowym od osób fizycznych oraz ustawy o podatku dochodowym od osób prawnych (Dz.U. 2017 poz. 1448) (2017). 